\title{
Sarah Z. Burke and Patrice Milewski, Eds. Schooling in Transition: Readings in Canadian History of Education
}

\author{
Toronto: University of Toronto Press, 2012. 426 pp.
}

\section{Frances Helyar \\ Lakehead University}

In compiling Schooling in Transition, editors Sarah Z. Burke and Patrice Milewski have provided students and instructors in history of education courses with a muchneeded resource. This volume, over 400 pages in length, brings together twentyfour previously published English language articles and book chapters to describe the history of education in Canada. Two-thirds were first published in the 1990s, and one-quarter in the 2000s. Four pre-1990 essays are what the editors term "classic studies" by R.D. Gidney and D.A. Lawr, Neil McDonald, Robert McIntosh and Neil Sutherland. The readings are paired according to theme, with three short explanatory paragraphs to introduce each pairing. Each introduction concludes with a list of suggested further readings. Themes range from colonial education to schooling in the 1990s. The geographic coverage of the collection is representative of the state of English Canadian historiography of the past forty years, with pieces pertaining to most regions of Canada, although the greater emphasis is on Ontario and the West.

The front end paper of the book contains a succinct description of its intended audience: students in a single-semester university-level course. The editors do not specify that this must be a history course, and indeed, many of the essays could be utilized in courses other than history, especially foundations. For example, sociology of education courses could benefit from the inclusion of the policy-based essays, and a women's studies course might be enlivened by the essays about the work of women teachers. However, the main use of this volume will likely be as a required anthology for a history of education course, and as such, the collection addresses a wide range of historical issues which resonate with today's teacher candidates and connect well with other parts of their pre-service program. Racism, immigration, language, multicultural and indigenous education are among the topics represented in essays written 
by many of Canada's leading Anglophone historians of education. At a time when seminal, broad histories of education in Canada such as Philips' The Development of Education in Canada and Wilson, Stamp and Audet's Canadian Education: A History are no longer used in undergraduate programs, Schooling in Transition is an alternative for the new century. ${ }^{1}$

Every reading was previously published, most in scholarly journals and some as book chapters. This raises the question whether it is appropriate to ask students to buy this book at a retail cost of almost $\$ 50$ in paperback when they may access most of the content on the Internet for free? The presence of the World Wide Web has certainly transformed the way undergraduate students acquire reading materials. A 2003 American study found that undergraduates were more likely than faculty or graduate students to consult electronic rather than print resources, and were "more willing to live in a wholly online world." ${ }^{2}$ This transformation means that twentyfirst century students have at their fingertips an expanded range of materials, and a greatly increased number of ways to receive information and ideas. ${ }^{3}$ Yet for all their promise, digital materials have not usurped their hard copy counterparts, which remain basics of the typical university course. ${ }^{4}$ Although instructors may avail themselves of online materials, they are more likely to choose between textbook, course pack, or anthology.

The strengths of this volume make it well worth the cost, as they address many of the drawbacks of accessing the articles and book chapters individually through electronic means or in a course pack. The twenty-four articles themselves offer an impressive breadth of scholarship, and the themes into which they are organized represent many key issues in the history of education in Canada. The features of this book that provide the most compelling argument for use in an undergraduate course, however, are the introductory essays and the suggested reading lists. The introductions provide much needed background to aid students in contextualizing the readings, something that is unavailable if they merely access the articles in their original forms. The intended audience for the readings at the time of their first publication was not the undergraduate student; each introduction should aid greatly in the development of students' understanding of complex historical issues, and should help them to identify the connections drawing together different eras and disparate regions of the country. The suggested reading lists signal that Canadian educational historiography is a viable and fascinating area of research, and provide ideas for those students pursuing further study, whether for a term paper, graduate study or for their own interest's sake. Schooling in Transition should have a place as required reading in single term history of education or foundations courses just as the editors suggest, but it is an equally valuable resource for libraries in Education faculties, and for the professional library of any instructor of education courses desiring to introduce an historical component to a syllabus. 


\section{Notes}

1 Charles E. Phillips, The Development of Education in Canada (Toronto: Gage, 1957); J. Donald Wilson, Robert M. Stamp, and Louis-Philippe Audet, eds., Canadian education: A history (Scarborough ON: Prentice-Hall of Canada, 1970).

2 Amy Friedlander, "Dimensions and use of the scholarly information environment," (Washington DC: Digital Library Federation and Council on Library and Information Resources, 2003), 12.

3 Philip G. Altbach, Liz Reisberg, and Laura E. Rumbley, Trends in global higher education: Tracking an academic revolution. A report prepared for the UNESCO 2009 World Conference on Higher Education, (United Nations Educational Scientific and Cultural Organization, 2009).

4 James A. Buczynski, "Faculty begin to replace textbooks with 'freely' accessible online resources," Internet Reference Services Quarterly 11, no. 4 (2007); John B. Thompson, "Higher education publishing and the digital revolution," in Books in the digital age: The transformation of academic and higher education publishing in Britain and the United States (Cambridge UK: Polity Press, 2005). 